Published in final edited form as:

Lancet. 2016 September 17; 388(10050): 1215-1227. doi:10.1016/S0140-6736(16)30578-5.

\title{
HIV and tuberculosis in prisons in sub-Saharan Africa
}

\section{Lilanganee Telisinghe, MRCP,}

Field Epidemiology Services, Public Health England, Bristol, UK

University of Bristol, Bristol, UK

\section{Salome Charalambous, PhD,}

The Aurum Institute, Johannesburg, South Africa

School of Public Health, University of the Witwatersrand, Johannesburg, South Africa

\section{Stephanie M Topp, PhD,}

College of Public Health, Medical and Veterinary Sciences, James Cook University, Townsville,

QLD, Australia

Centre for Infectious Disease Research in Zambia (CIDRZ), Lusaka, Zambia

Michael E Herce, MD,

Centre for Infectious Disease Research in Zambia (CIDRZ), Lusaka, Zambia

University of North Carolina School of Medicine, Chapel Hill, NC, USA

\section{Christopher J Hoffmann, MD,}

Johns Hopkins University School of Medicine, Baltimore, MD, USA

\section{Peter Barron, FFCH,}

School of Public Health, University of the Witwatersrand, Johannesburg, South Africa

\section{Erik J Schouten, MD,}

Management Sciences for Health, Lilongwe, Malawi

Andreas Jahn, PhD,

Department of HIV and AIDS, Ministry of Health, Lilongwe, Malawi

International Training and Education Center for Health, Department of Global Health, University of Washington, Seattle, WA, USA

\section{Rony Zachariah, PhD,}

Médecins Sans Frontières, Brussels Operational Centre, Operational Research Unit, Luxembourg City, Luxembourg

\footnotetext{
Correspondence to: Dr Lily Telisinghe, Public Health England, 2 Rivergate, Temple Quay, Bristol BS1 6EH, UK lily.telisinghe@phe.gov.uk.

This is the fifth in a Series of six papers about HIV and related infections in prisoners

Contributors

All authors contributed to the design of the study. LT, SC, SMT, MEH, CJH, and JJA undertook the searches and case studies, interpreted the findings, and wrote the Series paper. EJS, RZ, and ADH provided data or information for the study. All authors reviewed and edited the final paper.

Declaration of interests

We declare no competing interests.
} 
Prof Anthony D Harries, MD, International Union Against Tuberculosis and Lung Disease, Paris, France

London School of Hygiene \& Tropical Medicine, London, UK

Prof. Chris Beyrer, MD, and

Department of Epidemiology, Johns Hopkins Bloomberg School of Public Health, Baltimore, MD, USA

Joseph J Amon, PhD

Department of Epidemiology, Johns Hopkins Bloomberg School of Public Health, Baltimore, MD, USA

Health and Human Rights Division, Human Rights Watch, New York, NY, USA

\section{Abstract}

Given the dual epidemics of HIV and tuberculosis in sub-Saharan Africa and evidence suggesting a disproportionate burden of these diseases among detainees in the region, we aimed to investigate the epidemiology of HIV and tuberculosis in prison populations, describe services available and challenges to service delivery, and identify priority areas for programmatically relevant research in sub-Saharan African prisons. To this end, we reviewed literature on HIV and tuberculosis in subSaharan African prisons published between 2011 and 2015, and identified data from only 24 of the 49 countries in the region. Where data were available, they were frequently of poor quality and rarely nationally representative. Prevalence of HIV infection ranged from $2.3 \%$ to $34.9 \%$, and of tuberculosis from 0.4 to $16.3 \%$; detainees nearly always had a higher prevalence of both diseases than did the non-incarcerated population in the same country. We identified barriers to prevention, treatment, and care services in published work and through five case studies of prison health policies and services in Zambia, South Africa, Malawi, Nigeria, and Benin. These barriers included severe financial and human-resource limitations and fragmented referral systems that prevent continuity of care when detainees cycle into and out of prison, or move between prisons. These challenges are set against the backdrop of weak health and criminal-justice systems, high rates of pre-trial detention, and overcrowding. A few examples of promising practices exist, including routine voluntary testing for HIV and screening for tuberculosis upon entry to South African and the largest Zambian prisons, reforms to pre-trial detention in South Africa, integration of mental health services into a health package in selected Malawian prisons, and task sharing to include detainees in care provision through peer-educator programmes in Rwanda, Zimbabwe, Zambia, and South Africa. However, substantial additional investments are required throughout sub-Saharan Africa to develop country-level policy guidance, build human-resource capacity, and strengthen prison health systems to ensure universal access to HIV and tuberculsosis prevention, treatment, and care of a standard that meets international goals and human rights obligations.

\section{Background}

Countries in sub-Saharan Africa have borne the brunt of the generalised HIV and tuberculosis epidemics, which have strained health systems and devastated populations in the region. ${ }^{1,2}$ As reported by Dolan and colleagues ${ }^{3}$ in another paper in this Series, the prevalence of HIV infection among detainees was $15.6 \%$ (95\% CI 11.8-19.8\%) in east and 
southern Africa and 8.2\% (6.2-10.5) in west and central Africa, suggesting a higher prevalence in prison populations than in non-incarcerated populations. Prevalence of tuberculosis was also extremely high: it was estimated at 5.3\% (2.1-10.0) in east and southern Africa, and 2.9\% (2.4-3.6) in west and central Africa. ${ }^{3}$

To control the HIV and tuberculosis epidemics and achieve ambitious international targets, countries are called upon to scale up prevention, testing, and treatment for vulnerable groups, including detainees. ${ }^{4,5}$ Although in carceration necessarily restricts liberty, detainees have a right to a minimum standard of health care at least equivalent to that in the community, ${ }^{6,7}$ including effective services along the entire continuum of HIV and tuberculosis prevention, treatment, and care.

In this Series paper, we provide a descriptive overview of prison populations in sub-Saharan Africa and the epidemiology of HIV and tuberculosis therein; discuss policies and interventions for the prevention, diagnosis, and treatment of HIV and tuberculosis within these populations, and the barriers to their implementation; and recommend a policy and service-delivery agenda for detainee health in sub-Saharan Africa, together with the associated research agenda.

\section{Overview of methods}

Full methods and a full list of search terms are detailed in the appendix. In brief, we reviewed grey and peer-reviewed literature published between Jan 1, 2011, and Dec 31, 2015, to identify available abstracts, publications, and other reports (published in English, French, or Portuguese) on HIV and tuberculosis epidemiology in prison populations in subSaharan Africa, and approaches to prevention, screening, diagnosis, and treatment of these diseases. When no data were available after 2011, the most recent literature before 2011 was included instead. We did case studies in five countries (Zambia, South Africa, Malawi, Nigeria, and Benin), which were purposively selected on the basis of regional spread and data availability to examine prison-specific HIV and tuberculosis policies and services in different regions of sub-Saharan Africa. Information about international donor funding between 2005 and 2015 was sought from four major international donors: the Global Fund Against AIDS, Tuberculosis and Malaria, the US President's Emergency Plan for AIDS Relief, the UK Department for International Development, and the European Union Funding Programme (panel 1).

In this paper, we use the term "detainee" to represent both people awaiting trial (on-remand detainees) and those who have been sentenced (convicted detainees). The term "prison" is used to represent facilities housing on-remand detainees (including jails, police holding cells, and other detention centres) and convicted detainees. We specify when data pertains to only one group or type of facility. This review does not include information about prison staff.

\section{Prison populations in sub-Saharan Africa}

Between 2011 and 2015, the estimated average daily census of detainees in sub-Saharan Africa was around 600000 (table, appendix). ${ }^{9}$ On-remand detainees constitute $50 \%$ or more 
of the prison population in $40 \%$ of countries. 23 countries reported occupancy of more than $150 \%$. Accounts of prison conditions are scarce and are likely to vary across countries. However, food rationing and poor-quality food (Mwapasa V, College of Medicine, Blantyre, Malawi, personal communication); ${ }^{10,11}$ poor hygiene, water supply, and sanitation (Mwapasa V, College of Medicine, Blantyre, Malawi, personal communication); ${ }^{10,11}$ frequent stockouts of basic drugs, including antibiotics (Mwapasa V, College of Medicine, Blantyre, Malawi, personal communication; unpublished UN Office on Drugs and Crime Data); and physical and psychological abuse ${ }^{11}$ have all been reported. Such poor prison conditions-including overcrowding - are inconsistent with the basic principles set forth in the Mandela Rules, could constitute human rights violations, and pose serious risks to individual and public health (panel 2). ${ }^{7}$

Even among the prison population as a whole, access to health care, treatment of prisoners, and prison conditions differ substantially between specific groups. Ethnic minorities, migrants, poor people, foreigners, and socially marginalised populations such as sex workers, people who use drugs, lesbian, gay, bisexual, and transgender (LGBT) indivi duals, and on-remand detainees could be at increased risk of abuse, poor conditions, or lack of access to care. ${ }^{6,16}$ Women and juvenile detainees, who have increased and distinct health needs, constitute $5 \%$ or less of the prison population in most countries, but often have poorer access to high-quality health care than do male detainees (panel 3). ${ }^{18,19}$

\section{Epidemiology of HIV and tuberculosis among detainees in sub-Saharan Africa}

Data for HIV or tuberculosis in prisons, published between 2011 and 2015, were identified from 24 of 49 sub-Saharan African countries (appendix). Data published before 2011 were available for three other countries. Studies were limited in number, varied in quality, and had differing methods (panel 1). Therefore caution is advised when comparing or generalising findings and making inferences from the data.

Most studies consistently showed a higher prevalence of HIV infection and tuberculosis among detainees than among unmatched non-incarcerated populations. Reported prevalence of HIV infection ranged from $2.3 \%$ to $34.9 \%(2.3 \%-10.8 \%$ in west Africa; $4.2 \%-23.0 \%$ in east Africa; and 7.2\%-34.9\% in southern Africa); tuberculosis prevalence ranged from $0.4 \%$ to $16.3 \%(1.2 \%-16.3 \%$ in west Africa; $0.5 \%-12.1 \%$ in east Africa; and $3.6 \%-7.6 \%$ in southern Africa).

Female sex was associated with prevalent HIV infection in prison; prevalence was also higher in women in prison than in those in the surrounding or non-incarcerated population. Although the reasons for this increased prevalence are unclear, the high background prevalence of HIV infection among younger women or behaviours associated with both incarceration and HIV, such as sex work, could have roles. One cross-sectional study ${ }^{20}$ in Zambia showed a higher prevalence among already-incarcerated detainees than among those entering prison. Whether HIV transmission during incarceration or other epidemiological factors contributed to this difference is unclear. 
When data were available, a large proportion of tuberculosis cases were in people with HIV (range 5-70\%). ${ }^{10,21-28}$ Overcrowding, incarceration in windowless cells, and sharing cells with patients with tuberculosis or a chronic cough were associated with increased tuberculosis prevalence among detainees in some studies. Furthermore, in a modelling study in a South African prison, annual tuberculosis transmission risk was estimated to be as high as $90 \%,{ }^{29}$ suggesting that prisons could be places of high transmission intensity.

The revolving-door effect (appendix) — as a result of detainees, prison personnel, and visitors cycling into and out of prisons-can result in the concentration of HIV and tuberculosis in prisons, and could amplify these diseases in the wider communities into which detainees are released and in which prison personnel live. ${ }^{20,30}$ For example, in a study in Zambia, ${ }^{20}$ the total prison population over 6 months was double the average static population $(n=1300)$ for that period, and $24 \%$ of detainees entering prison had been previously incarcerated. Several other studies have also shown the high turnover of detainees. ${ }^{10,21,31,32}$ Therefore, HIV and tuberculosis control in prisons benefits not only the individual and other detainees, but could also affect control in the community. Additionally, community and prison HIV and tuber culosis programmes face substantial challenges in ensuring appropriate services and continuity of care for detainees upon incarceration and release.

Understanding risk factors for HIV and tuberculosis in sub-Saharan African prisons is essential to the implementation of appropriate prevention interventions and services. The available empirical data do not allow determination of the relative contribution of transmission before and after incarceration to prevalence within prisons. The very limited data available suggest, however, that transmission during both periods might play a part. Robust studies of the bio-behavioural, social, and structural factors underpinning the risk of HIV and tuberculosis among prison populations in sub-Saharan Africa are needed to answer these questions.

\section{Tools, approaches, and structural interventions to prevention, screening, diagnosis, and treatment}

International guidelines recommend a package of HIV and tuberculosis interventions for prisons in low-income and middle-income countries. ${ }^{7,33}$ The recommended interventions can be organised into three categories: structural approaches to reduce overcrowding, improve tuberculosis infection control, and provide adequate nutrition; prevention and harmreduction activities, including interventions to reduce transmission of HIV and tuberculosis; and HIV and tuberculosis diagnosis, treatment, and care, which should adhere to national guidelines and be linked operationally to national programmes.

Despite endorsement from regional and international governing bodies, ${ }^{34,35}$ these interventions are rarely fully available in sub-Saharan African prisons because of a host of financial, policy, and systems-related barriers, including financial constraints, ${ }^{36}$ inadequate infrastructure, ${ }^{37}$ laws criminalising sex between men, ${ }^{38}$ overcrowding,,${ }^{39}$ absent healthinformation management systems, ${ }^{39}$ inadequate infection-control procedures, ${ }^{40}$ lack of transport to off-site clinics, ${ }^{39}$ fragmented care due to facility transfers and release back to the community, ${ }^{39}$ and scarce human resources for health. ${ }^{39}$ 
Prison overcrowding is a recognised problem globally, ${ }^{36}$ and mathematical modelling suggests that imple mentation of internationally recommended cell-occupancy standards could reduce the annual risk of tuberculosis transmission by $50 \%$ in the specific case of South Africa. ${ }^{29}$ However, there are limited data from sub-Saharan African countries describing the use of structural or criminal-justice interventions to mitigate overcrowding. ${ }^{39}$ South Africa provides a counter-example: reforms to the pre-trial detention system have helped to reduce overcrowding by creating alternatives to detention for on-remand detainees unable to post bail, including release on warning and the use of electronic monitors. ${ }^{41-43}$ Partly as a result of these reforms, the South African prison population declined between 2004 and 2014, from 187036 to 157170 detainees. ${ }^{44}$ Another policy change identified in one prison was increasing food rations, which correlated with a reduction in reported tuberculosis incidence and all-cause mortality. ${ }^{45}$

In some cases, better service delivery for HIV and tuberculosis prevention and treatment could be politically and logistically more feasible than structural changes as a first step towards improvement of detainees' health. With respect to HIV prevention, behaviourchange communication and educational interventions have been implemented in some prisons, although their reach and effectiveness are unknown. ${ }^{37,46-48}$ Crucial concerns, such as mitigation of sexual violence and coerced sex, ${ }^{49}$ appear to be minimally addressed, with no reports of clearly effective strategies. ${ }^{50,51}$ Provision of condoms, post -exposure prophylaxis, and pre-exposure prophylaxis could reduce HIV transmission in facilities. Condoms are available in prisons in Burundi, Lesotho, and South Africa; ${ }^{38}$ nonoccupational post-exposure prophylaxis is reported to be available only in South Africa. Data for uptake (how often, when, and by which detainees) or effectiveness of these preventive measures are unavailable. Condom provision is illegal in prisons in many countries, including Ethiopia, Malawi, Namibia, Rwanda, Senegal, Swaziland, Tanzania, Uganda, Zambia, and Zimbabwe. We identified no reports suggesting that pre-exposure prophylaxis is being prepared for implementation in sub-Saharan African prisons at present.

International guidelines state that mandatory HIV testing is a violation of human rights and endorse the availability of voluntary, confidential, on-site HIV counselling and testing for all people within closed settings. ${ }^{52}$ Despite potential concerns about stigma, voluntary HIV counselling and testing seems to be accepted by detainees, as shown by several reports of uptake and a study of detainee satisfaction. ${ }^{10,20,32,53-55}$ It is available in prisons in some countries, including Cameroon, ${ }^{56}$ Côte d'Ivoire, ${ }^{10}$ Democratic Republic of the Congo, ${ }^{53}$ Kenya, ${ }^{46,57}$ Malawi, ${ }^{58}$ South Africa, ${ }^{31}$ Uganda, ${ }^{37}$ and Zambia. ${ }^{59}$

Although the availability of antiretroviral therapy (ART) in prisons in sub-Saharan Africa is limited, ${ }^{30,31,60}$ when combined with comprehensive, voluntary HIV counselling and testing, initiation of ART can, in some cases, occur earlier in prisons than in the community. For example, the median CD4 cell count among male detainees initiating ART in South Africa appears higher than that among men in neighbouring community programmes. ${ }^{31,61,62}$ Once in care, people who remain in prison can achieve excellent clinical outcomes: viral-load suppression was $93 \%$ at 12 months at an on-site treatment clinic ${ }^{31}$ and $92 \%$ at 96 weeks at an off-site HIV clinic. ${ }^{60} \mathrm{~A}$ description of the HIV treatment continuum in Kenyan prisons suggests that service uptake along the cascade might be similar to that in the community, and 
is in need of strengthening: 48535 detainees received HIV counselling and testing and 2782 (5.7\%) received a diagnosis of HIV, of whom 1493 (53.7\%) enrolled into HIV care and 505 initiated ART (18.2\%). ${ }^{46,63}$

Frequently set apart from HIV services, tuberculosis prevention activities in prisons have historically involved passive approaches to case detection. ${ }^{29,64}$ By contrast, active casefinding - the aims of which are to systematically screen, diagnose, and treat detainees with tuberculosis early, with the goal of interrupting transmission - has been reported in prisons in Cameroon, ${ }^{32}$ Malawi, ${ }^{65}$ Nigeria,${ }^{66}$ South Africa,${ }^{67}$ Tanzania, ${ }^{68}$ and Zambia.${ }^{59}$ Evidence shows that, with support and funding from implementing partners, mass and at-entry screening for tuberculosis - frequently integrated with HIV counselling and testing-is feasible, acceptable, and results in high uptake..$^{20,59,69}$ In Zambia in 2010, through a collaboration between the Zambia Correctional Service, Ministry of Health, and a Zambian non-governmental organisation (NGO), 4879 detainees and neighbouring community members were screened for HIV, and 7638 for tuberculosis; ${ }^{59} 564$ individuals were newly diagnosed with HIV and linked to care, and 409 were diagnosed with tuberculosis, with 372 $(91 \%)$ initiating treatment. These results demonstrate what can be achieved when prison leadership, donor funding, and NGOs align to support implementation of tuberculosis programmes in prisons. Nonetheless, solutions embedded within and linking prisons and mainstream health systems will be required to achieve sustained screening, service-delivery, and health improvements.

To maximise efficiency and control costs, evidence-based screening tools are needed, ${ }^{70}$ but few reports from sub-Saharan Africa have been published to guide how to screen detainees for tuberculosis. The sensitivity and specificity of symptom screening varies depending on the number of symptoms included. ${ }^{27,70}$ In Zambian detainees, low body-mass index and HIV infection had moderate sensitivity (60\%) for tuberculosis. ${ }^{70}$ Among South African detainees, the use of chest radiography in addition to symptoms improved screening sensitivity from $24-38 \%$ to $70-80 \% .{ }^{27}$ These results are in keeping with findings from other continents, ${ }^{71,72}$ which suggests that use of chest radiography is beneficial among prison populations. However, chest radiography necessitates resources, including health-care workers or computer-aided diagnostic algorithms to interpret or score radiographs, respectively.

Tuberculosis diagnosis in sub-Saharan African prisons often relies on sputum smear microscopy, (usually performed off site), ${ }^{28}$ which misses about half of all cases. ${ }^{73}$ Improving access to tuberculosis culture, chest radiography, and newer nucleic acid amplification tests could increase diagnostic yield in prisons and allow for earlier detection of multidrug-resistant tuberculosis. In South Africa, testing symptomatic on-remand and convicted detainees (both new entrants and those incarcerated) identified by the WHO symptom screen ${ }^{74}$ with on-site nucleic acid amplification was feasible and affordable: $87 \%$ of all new entrants and $23 \%$ of incarcerated detainees were reached, and costs were similar to those of other screening modalities (US\$1513 per case of tuberculosis identified) ${ }^{67}$

Some evidence suggests that detainees in sub-Saharan Africa might experience suboptimal retention along the tuberculosis care continuum. Among 466 detainees beginning 
tuberculosis treatment at ten regional Ugandan prison health centres, only 222 (48\%) completed treatment (202 [43\%] were lost to follow-up and 22 [5\%] died). ${ }^{22} \mathrm{~A}$ chart review $^{75}$ of 202 detainees initiating tuberculosis treatment at one South African prison showed similar challenges: 92 (46\%) patients were cured, but $103(51 \%)$ had no ascertainable outcome because they were transferred before treatment completion. Findings that less than $50 \%$ of patients completed treatment or had documented cure are concerning, and have implications for the health of detainees and the potential development of drugresistant tuberculosis. Early reports suggested a high prevalence $(9.5 \%)$ of multidrugresistant tuberculosis in one Zambian prison. ${ }^{76}$ However, subsequent studies in Zambia ${ }^{20}$ and South Africa ${ }^{67}$ have shown a much lower prevalence (1.1\% and $1.0 \%$, respectively) similar to general population estimates in sub-Saharan Africa (1.5\% prevalence among treatment-naive patients with tuberculosis), ${ }^{77}$ suggesting that detainees might not be disproportionately affected by multidrug-resistant disease. Screening, diagnosis, and effective treatment should be linked to preventive therapy (ie, isoniazid preventive therapy and ART) to control tuberculosis in high-risk populations such as detainees. ${ }^{78}$ No published reports from sub-Saharan African prisons include descriptions of initiation or completion of isoniazid preventive therapy, or associated adverse events. ${ }^{79}$ There was a notable dearth of sex-disaggregated and age-disaggregated data describing HIV or tuberculosis treatment outcomes for women and children within sub-Saharan African prisons. ${ }^{19}$

The breakdown of continuity of care for HIV and tuberculosis as a result of inter-facility transfer and release have been frequently noted. ${ }^{31,60}$ The transition into detention often starts in police detention facilities or holding cells within police stations-facilities that generally lack health services. ${ }^{80,81}$ For individuals already on ART or tuberculosis treatment, or both, who transition into prison, breaks in treatment of as little as several days can have serious adverse consequences, including the development of drug resistance. ${ }^{82}$ Within prison and after release from prison, continuation of ART and tuberculosis treatment is essential for sustainment of individual health, prevention of development of drug resistance, and reduction of the risk of transmission to other detainees and the communities into which detainees are released. On the basis of data largely from Europe and North America, ${ }^{83-85}$ retention in HIV or tuberculosis care, or both, after release from prison is thought to be challenging for various psychosocial, health-systems, and structural reasons. In the only subSaharan African study ${ }^{60}$ in which retention in HIV care after release is discussed, 23 (68\%) of 34 detainees visited the same South African HIV clinic at which they received care during incarceration at least once after release.

Prison populations are likely to have a higher prevalence of substance-use and mental health problems than the general population. These issues can compromise HIV and tuberculosis prevention, treatment, and care efforts within prisons through poor adherence to treatment, transactional sex for drugs, and high-risk sexual behaviours. ${ }^{55,86,87}$ However, data for prevalence and strategies to address these issues are scarce. Substance use in the past month (mostly cannabis or alcohol) has been reported by about $5 \%$ of detainees in Nigeria ${ }^{88}$ and Kenya ${ }^{89}$ In a South African study ${ }^{90}$ in which urine testing was done, either cannabis or methaqualone was detected among $45 \%$ of detainees at the time of police arrest. Although anecdotal reports describe the use of injection drugs in sub-Saharan African prisons, the frequency is unknown, but appears low. ${ }^{89}$ Depressive and anxiety disorders have been 
reported in a large proportion of detainees in several studies. ${ }^{91,92}$ Despite the probable burden of these comorbidities, we identified only one description of mental health activities (in Malawi) ${ }^{93}$ and one drug harm-reduction programme (in Mauritius) in prisons. ${ }^{94}$

The lack of sufficient numbers of health workers and training 95 to provide HIV and tuberculosis treatment and other services ${ }^{95}$ is a severe constraint on delivering care in subSaharan African prisons. Task-sharing and involving detainees themselves in health-service delivery could help to overcome some gaps in the system. ${ }^{59,96}$ Reports from Rwanda, South Africa, Zambia, and Zimbabwe highlight the role of inmate peer educators in the provision of a host of services, including health education, psychosocial support, symptom screening and sputum collection for tuberculosis, referral for HIV testing, and social mobilisation for uptake of health services. ${ }^{48,97-99}$ Sustainment of these programmes necessitates dedicated financing, ongoing training and peer-to-peer mentoring to maintain the cadre, and training of prison personnel to supervise and support peer educators. ${ }^{59,97}$

\section{HIV and tuberculosis prevention, care, and treatment policies, and availability of services}

Few sub-Saharan African countries have comprehensive policies in place guiding the implementation of HIV and tuberculosis prevention, care, and treatment activities in prisons. The appendix shows differing progress in this field, with summaries of the state of HIV and tuberculosis policies for detainees in five countries. Whereas South Africa has fully developed prison guidelines for tuberculosis, HIV, and sexually transmitted infections that outline a comprehensive package of interventions specific to detainees, prisons in Benin, Zambia, and Nigeria remain dependent on guidelines developed for the general community, with little or no reference to the epidemiological or structural particularities of prison populations. Malawi has a specific policy for tuberculosis management in prisons, but not for HIV or other sexually transmitted infections.

Policies provide clarity, direction, and normative standards to guide planning and service implementation and help to hold government institutions accountable. But, as shown by experiences in South Africa and Malawi (panel 4), comprehensive policies are not a guarantee of service implementation or operational efficacy (appendix). As demonstrated by Zambia and Benin (panel 5), innovations to improve HIV and tuberculosis care in prisons are possible despite weak or absent policies, but will probably remain limited in their sustainability and strategic impact (appendix). In many countries, NGOs often make a large and unmeasured contribution to essential services. ${ }^{102}$

\section{International donor funding for HIV and tuberculosis services within prisons}

Estimation of total national funding for prevention and treatment services for HIV and tuberculosis in prisons is complicated by multiple funding sources and frequent lack of transparency in the reporting of funding. Funding can come from domestic government, NGOs, and international donor sources, and could be channelled through health, justice, or 
interior ministries, or through NGO interventions. Available data for domestic funding, although sought, were not comprehensive and therefore are not presented. We also sought information about international donor funding from four major funders, which is presented.

Among the Global Fund to Fight AIDS, Tuberculosis and Malaria's grant agreements to 49 sub-Saharan African countries between 2005 and 2015, only 24 included indicators of prison-related HIV or tuberculosis initiatives. Total funding for these activities was less than $\$ 100000$ in seven countries; another five countries reported more than $\$ 1000000$ in prisonrelated funding (table). In 15 countries, less than 5\% of the total budget for HIV and tuberculosis programmes was allocated to interventions in prisons.

Planning and budgeting documents for 2007-14 for the 21 sub-Saharan African countries that are part of the US President's Emergency Plan for AIDS Relief included references to HIV or tuberculosis pro grammes, or both, addressing prisoners in all countries, except South Sudan. The most frequently proposed intervention was HIV testing (16 [80\%] of 20 countries). Other frequently proposed programmes mentioning prisons included HIV treatment, technical assistance, and research (11 countries [55\%]); tuberculosis case-finding, abstinence, and general education about HIV prevention (eight countries [40\%]); programmes for prison staff (six countries [30\%]); and tuberculosis treatment (five countries [25\%]). With the exception of Ethiopia and Kenya, prison-related funding for HIV and tuberculosis was rarely continuous (data not shown). Many of the interventions in which detainees were mentioned were part of larger programmes targeting most-at-risk populations, making it difficult to determine if —and the extent to which-programme activities actually included prison-specific activities.

Only one prison-related programme supported by the UK Department for International Development was identified: the Evidence for HIV Prevention in Southern Africa project. This initiative provides funding for research into HIV prevention in key populations, including detainees, in sub-Saharan Africa, with two research projects funded in 2015. Although the European Union did not provide information about prison programmes funded in sub-Saharan Africa, experts in the field report two projects funded by them-a 3 year project targeting health-systems strengthening in Zambian prisons, which began in February, 2013, and a multi-year project to build prison-service capacity to protect detainees' human rights in Uganda. ${ }^{103,104}$

\section{A policy, service-delivery, and research agenda for detainee health in sub- Saharan African prisons}

Provision of HIV and tuberculosis prevention and care services for detained populations is not only a human right, but also crucial for overall disease prevention and improved population health. To understand and address the gaps in HIV and tuberculosis services in prisons, political will, leadership, operationally relevant research, and long-term funding are needed to enable implementation of crucial programmes. Greater transparency and accountability are also needed to ensure that interventions and reforms are properly implemented and detainee rights are respected. 
Reflecting the low political priority of detainees as a group, prison-specific policy guidance and adequate sustained funding for health-service delivery in prisons are absent in many sub-Saharan African countries - an issue that needs to be urgently addressed. Additionally, donors and governments have an obligation to report funding transparently, and should support efforts to track detainee health funding from domestic and international sources to ensure comprehensive coverage of prevention and treatment programmes.

Although specific interventions for HIV and tuberculosis are important, an overall healthsystems-strengthening approach is required in prisons to address the pervasive barriers of poor infrastructure, shortages of human resources for health, scarce medical supplies, and inadequate information systems. Specific reforms include the adoption of a harmonised, intersectoral approach to recruitment, supervision, and remuneration of prison health professionals and the inclusion of prisons in quarterly facility-based reviews by community HIV and tuberculosis programmes. Such actions could form the basis for implementation of comprehensive, integrated screening, diagnosis, and treatment services for HIV and tuberculosis - as well as nutrition, substance-use, and mental health services-within a primary care framework, tailored to the prison context, and linked to community services. Services provided by NGOs should also be integrated into, and aligned with, prison and mainstream health systems to promote local ownership and ensure a continuum of care.

Criminal-justice reforms that address policies or practices that limit bail and reduce long delays in access to courts would probably reduce exposure to, and incidence of, disease. Limitation of arbitrary and extended pre-trial detention is a cost-effective criminal justice measure, as are large-scale interventions such as release of people detained for minor, nonviolent offences. Interventions such as reformation of bail guidelines, restriction of overly broad police authority to detain so-called co-conspirators with no evidence, expansion of community service and parole programmes, increasing the numbers of judges, and improvement of access to legal representation, could all contribute to the reduction of prison populations in a sustained manner. ${ }^{39}$ These interventions would probably reduce the risk of acquiring HIV and tuberculosis and recidivism, facilitate access to care, and ensure respect for international laws requiring prompt access to justice and freedom from pre-trial detention except in exceptional circumstances.

Strengthening of prison health and criminal-justice systems will require engagement by advocacy groups and civil society to raise attention and apply political pressure for reform. Where improvements in prevention and treatment services have occurred, advocacy or legal action, or both, have frequently been instrumental (eg, Botswana withheld ART from noncitizen detainees until a constitutional court overturned this policy, ${ }^{105}$ South Africa expanded HIV and tuberculosis services in prisons in response to legal action).

Optimal prevention and treatment strategies are best implemented when informed by regularly updated epidemiological and programmatic data. These data should inform priority health-service needs, service-implementation strategies, and guidelines within countries. The transparency of these data will enable best practices in the region to be shared. Priority programme and research questions that could guide the evidence-based implementation of services within prisons include sensitive entry and mass-screening algorithms for 
tuberculosis with universal access to diagnostic testing; the feasibility, uptake, and completion of isoniazid preventive therapy with or without ART and effects on tuberculosis epidemiology; and the burden and causes of mental health and substance-use problems and their association with HIV and tuberculosis epidemiology and clinical outcomes. Additional robust evidence of longitudinal clinical outcomes and linkage to and retention in highquality treatment services for HIV and tuberculosis for prison populations was notably lacking. Implementation and assessment of new strategies are urgently needed to reinforce a continuum of care for detainees at incarceration, during inter-facility transfer, and after release. Additionally, it is important to understand the differing needs of ethnic minorities, children, migrants, LGBT people, people with disabilities, and people who use drugs in prisons, and to ensure effective and tailored services.

\section{Conclusion}

Good-quality data for HIV and tuberculosis in prisons in sub-Saharan Africa are rare; recent (ie, in the past 5 years) research is lacking in more than half the countries, and capacity to determine national estimates or monitor trends is limited. Available data suggest inadequate health services incommensurate with high disease burden. Funding is minimal, and policies guiding service implementation are often missing. Although some promising practices exist, increased political commitment and dedicated resources are needed to ensure universal access to high-quality prevention, treatment, and care of HIV and tuberculosis for detainees in sub-Saharan Africa.

\section{Supplementary Material}

Refer to Web version on PubMed Central for supplementary material.

\section{Acknowledgments}

This Series on HIV and prisoners was supported by grants to the Center for Public Health and Human Rights at Johns Hopkins Bloomberg School of Public Health from the National Institute on Drug Abuse, the Open Society Foundations, the UN Population Fund, and the Johns Hopkins University Center for AIDS Research (a NationalInstitutes-of-Health-funded programme; 1P30AI094189). The content is solely the responsibility of the authors and does not necessarily represent the official views of the National Institutes of Health. We thank detainees throughout sub-Saharan Africa who participated in the studies cited in this paper.

\section{References}

1. WHO. Global Health Observatory data. http://www.who.int/gho/hiv/en/ (accessed Jan 1, 2016)

2. Corbett EL, Marston B, Churchyard GJ, De Cock KM. Tuberculosis in sub-Saharan Africa: opportunities, challenges, and change in the era of antiretroviral treatment. Lancet. 2006; 367:92637. [PubMed: 16546541]

3. Dolan K, Wirtz AL, Moazen B. , et al. Global burden of HIV, viral hepatitis, and tuberculosis in prisoners and detainees. Lancet. 2016. published online July 14.

4. UNAIDS. 90-90-90: an ambitious treatment target to help end the AIDS epidemic. http:// www.unaids.org/sites/default/files/media_asset/90-90-90_en_0.pdf (accessed Jan 1, 2016)

5. WHO. The End TB Strategy. 2015. http://www.who.int/tb/post2015_TBstrategy.pdf?ua=1 (accessed Jan 1, 2016)

6. Rubenstein L, Amon JJ, McLemore M. , et al. HIV, prisoners, and human rights. Lancet. 2016. published online July 14. 
7. UN. United Nations standard minimum rules for the treatment of prisoners (the Mandela rules). 2015. http://www.penalreform.org/wp-content/uploads/2015/05/MANDELA-RULES.pdf (accessed Jan 1, 2016)

8. Institute for Criminal Policy Research. World prison brief: Africa. www.prisonstudies.org/map/ africa (accessed March 29, 2016)

9. Institute for Criminal Policy Research. World prison population list. 11thhttp:// www.prisonstudies.org/sites/default/files/resources/downloads/ world_prison_population_list_11th_edition.pdf (accessed April 1, 2016)

10. Angora B, Assemien J, Laurent A, et al. HIV in prison in low income countries. AIDS. 2011; 25:1244-46. [PubMed: 21593624]

11. Human Rights Watch. "Even dead bodies must work": health, hard labor, and abuse in ugandan prisons. https://www.hrw.org/report/2011/07/14/even-dead-bodies-must-work/health-hard-laborand-abuse-ugandan-prisons (accessed Jan 1, 2016)

12. Human Rights Watch. "Prison is not for me": arbitrary detention in South Sudan. https:// www.hrw.org/report/2012/06/21/prison-not-me/arbitrary-detention-south-sudan (accessed Jan 1, 2016)

13. Human Rights Watch. "Treat us like human beings": discrimination against sex workers, sexual and gender minorities, and people who use drugs in Tanzania. https://www.hrw.org/report/ 2013/06/18/treat-us-human-beings/discrimination-against-sex-workers-sexual-and-gender (accessed Jan 1, 2016)

14. Human Rights Watch. "Why not call this place a prison?": unlawful detention and ill treatment in Rwanda's Gikondo Transit Center. https://www.hrw.org/report/2015/09/24/why-not-call-placeprison/unlawful-detention-and-ill-treatment-rwandas-gikondo (accessed Jan 1, 2016)

15. Todrys KW, Amon JJ, Malembeka G, et al. Imprisoned and imperiled: access to HIV and TB prevention and treatment, and denial of human rights, in Zambian prisons. J Int AIDS Soc. 2011; 14:8. [PubMed: 21314929]

16. Open Society Justice Initative. Presumption of guilt: the global overuse of pretial detention. https:// www.opensocietyfoundations.org/sites/default/files/presumption-guilt-09032014.pdf (accessed Jan 1, 2016)

17. Todrys KW, Amon JJ. Human rights and health among juvenile prisoners in Zambia. Int J Prison Health. 2011; 7:10-17.

18. Singh S. Legislation: the implementation of health policies in a female prison in Durban, South Africa. Agenda. 2009; 23:100-12.

19. Todrys KW, Amon JJ. Health and human rights of women imprisoned in Zambia. BMC Int Health Hum Rights. 2011; 11:8. [PubMed: 21696625]

20. Henostroza G, Topp SM, Hatwiinda S, et al. The high burden of tuberculosis (TB) and human immunodeficiency virus (HIV) in a large Zambian prison: a public health alert. PLoS One. 2013; 8:e67338. [PubMed: 23967048]

21. Noeske J, Ndi N, Mbondi S. Controlling tuberculosis in prisons against confinement conditions: a lost case? Experience from Cameroon. Int J Tuberc Lung Dis. 2011; 15:223-27. [PubMed: 21219685]

22. Schwitters A, Kaggwa M, Omiel P, Nagadya G, Kisa N, Dalal S. Tuberculosis incidence and treatment completion among Ugandan prison inmates. Int J Tuberc Lung Dis. 2014; 18:781-86. [PubMed: 24902552]

23. Angolwisye J, Kaymobo F, Nichombe F. , et al. First survey on TB and HIV prevalence in the prisons of the Mbeya region in Tanzania; 42nd World Conference on Lung Health of the International Union Against Tuberculosis and Lung Disease; Lille, France. Oct 26-30, 2011; 157

24. Gidado M, Onazi J, Obasanya J. , et al. TB case finding in Nigerian prisons: using health system strengthening approach; 45th World Conference on Lung Health of the International Union Against Tuberculosis and Lung Disease; Barcelona, Spain. Oct 28-Nov 1, 2014; 345

25. Wachinou A, Agodokpessi G, Ade SS, Kassa F, Tawo L. Epidemiologie de la tuberculose en milieu carceral au Benin; 43rd World Conference on Lung Health of the International Union Against Tuberculosis and Lung Disease; Kuala Lumpur, Malaysia. Nov 13-17, 2012; 372 
26. Ali S, Haileamlak A, Wieser A, et al. Prevalence of pulmonary tuberculosis among prison inmates in Ethiopia, a cross-sectional study. PLoS One. 2015; 10:e0144040. [PubMed: 26641654]

27. Telisinghe L, Fielding KL, Malden JL, et al. High tuberculosis prevalence in a South African prison: the need for routine tuberculosis screening. PLoS One. 2014; 9:e87262. [PubMed: 24498059]

28. Moges B, Amare B, Asfaw F, et al. Prevalence of smear positive pulmonary tuberculosis among prisoners in North Gondar Zone Prison, northwest Ethiopia. BMC Infect Dis. 2012; 12:352. [PubMed: 23241368]

29. Johnstone-Robertson S, Lawn SD, Welte A, Bekker LG, Wood R. Tuberculosis in a South African prison—a transmission modelling analysis. S Afr Med J. 2011; 101:809-13. [PubMed: 22272961]

30. Reid SE, Topp SM, Turnbull ER, et al. Tuberculosis and HIV control in sub-Saharan African prisons: "thinking outside the prison cell". J Infect Dis. 2012; 205(suppl 2):S265-73. [PubMed: 22448015]

31. Telisinghe L, Hippner P, Churchyard GJ, et al. Outcomes of on-site antiretroviral therapy provision in a South African correctional facility. Int J STD AIDS. 2015; published online May 4. doi: $10.1177 / 0956462415584467$

32. Noeske J, Ndi NF, Amougou Elo G, Mbondi Mfondih S. Tuberculosis incidence in Cameroonian prisons: a 1-year prospective study. S Afr Med J. 2014; 104:209-11. [PubMed: 24897826]

33. UN Office on Drugs and Crime, International Labour Organization, UNDP, WHO, UNAIDS. HIV prevention, treatment and care in prisons and other closed settings: a comprehensive package of interventions. https://www.unodc.org/documents/hiv-aids/ HIV_comprehensive_package_prison_2013_eBook.pdf (accessed Jan 1, 2016)

34. UN Office on Drugs and Crime, UNAIDS, World Bank. HIV and prisons in sub-Saharan Africa: opportunities for action. https://www.unodc.org/documents/hiv-aids/publications/ UNODC_UNAIDS_WB_2007_HIV_and_prisons_in_Africa-EN.pdf (accessed Jan 1, 2016)

35. Southern African Development Community (SADC) Secretariat. Minimum standards for HIV and AIDS, TB, hepatitis B and C, and sexually transmitted infections prevention, treatment, care and support in prisons in the SADC region. http://www.arasa.info/files/9214/2649/8510/ Minimum_Standards_for_HIV_and_AIDSTB_Hepatitis_B_and_C_and_SexuallyTransmitted_Inf ections_PreventionTreatment_Care_and_Support_in_Prisonsin_the_SADC_Region.pdf (accessed Jan 1, 2016)

36. Vinkeles Melchers NV, van Elsland SL, Lange JM, Borgdorff MW, van den Hombergh J. State of affairs of tuberculosis in prison facilities: a systematic review of screening practices and recommendations for best TB control. PLoS One. 2013; 8:e53644. [PubMed: 23372662]

37. Uganda Prisons Service, UN Office on Drugs and Crime. A rapid situation assessment of HIV/STI/TB and drug abuse among prisoners in Uganda Prisons Service: final report. https:// www.unodc.org/documents/hiv-aids/publications/RSA_Report.pdf (accessed Jan 1, 2016)

38. Kyomya M, Todyrs KW, Amon JJ. Laws against sodomy and the HIV epidemic in African prisons. Lancet. 2012; 380:310-12. [PubMed: 22819651]

39. Todrys KW, Amon JJ. Criminal justice reform as HIV and TB prevention in African prisons. PLoS Med. 2012; 9:e1001215. [PubMed: 22589705]

40. O'Grady J, Hoelscher M, Atun R, et al. Tuberculosis in prisons in sub-Saharan Africa-the need for improved health services, surveillance and control. Tuberculosis. 2011; 91:173-78. [PubMed: 21251881]

41. South African Broadcasting Corporation. Electronic tagging will reduce prison overcrowding in SA: Ndebele. http://www.sabc.co.za/news/a/a764600043a608c28ec6de239b19c088/Electronictagging-will-reduce-prison-overcrowding-in-SA:-Ndebele (accessed Jan 1, 2016)

42. Ensor L. Overcrowding in South African prisons falls. http://www.bdlive.co.za/national/ 2013/08/26/overcrowding-in-south-african-prisons-falls (accessed Jan 1, 2016)

43. Department of Correctional Services South Africa. Department of Correctional Services strategic plan 2013/2014-2016/2017. http://www.dcs.gov.za/Publications/Strategic\%20Plans/Strategic \%20Plan\%202013-2014\%20-2016-2017.pdf.pdf (accessed Jan 1, 2016) 
44. Masutha M. Correctional Services Budget Vote Speech-2014/15. http://www.dcs.gov.za/docs/ landing/Address \%20by\%20\%20Minister\%20Micheal\%20Masutha\%20at\%20the\%20Budget \%20Vote\%20Speech.pdf (accessed Jan 1, 2016)

45. Rasolofo-Razanamparany V, Menard D, Ratsitorahina M, Auregan G, Gicquel B, Chanteau S. Transmission of tuberculosis in the prison of Antananarivo (Madagascar). Res Microbiol. 2000; 151:785-95. [PubMed: 11130869]

46. Benson Otieno U, Chepkonga M, Kibosia J. , et al. Increased capacity for integrated HIV/TB services in Kenyan prisons; 6th IAS Conference on HIV Pathogenesis and Treatment; Rome, Italy. July 17-20, 2011; abstr CDD234

47. Maggard KR, Hatwiinda S, Harris JB, et al. Enhancing tuberculosis screening and HIV counseling and testing in Zambian prisons: implementation successes and lessons learned. Bull World Health Organ. 2015; 93:93-101. [PubMed: 25883402]

48. Tapfumaneyi W. Hear our voice! Speaking out for HIV services and care support in Zimbabwe; 19th International AIDS Conference; Washington, DC, USA. July 22-27, 2012; abstr TUPE301

49. Ingleby C, Tahuna S, Muchungu C. VSO and government of Malawi joint qualitative study identifies high incidence of forced and coerced sexual encounters between male prisoners in Malawi and resultant vulnerability to HIV and AIDS infection; 19th International AIDS Conference; Washington, DC, USA. July 22-27, 2012; abstr THPE567

50. Keehn E. Stopping sexual abuse and the spread of HIV amongst inmates: Sonke works in 10 South African correctional centres. http://www.genderjustice.org.za/article/stopping-sexual-abuse-andthe-spread-of-hiv-amongst-inmates-sonke-works-in-10-south-african-correctional-centres/ (accessed Dec 19, 2015)

51. Lotter JM. Prison gangs in South Africa. A description. S Afr J Sociol. 1988; 19:67-75.

52. UN Office on Drugs and Crime, UNAIDS, WHO. HIV testing and counselling in prisons and other closed settings. https://www.unodc.org/documents/hiv-aids/ UNODC_WHO_UNAIDS_2009_Policy_brief_HIV_TC_in_prisons_ebook_ENG.pdf (accessed Jan 1, 2016)

53. Mashako KY, Sebahire V, Murhabazi V. HIV care and prevention in prison in a country in conflict: community approach in SOFEDI, Bukavu, DR Congo; 19th International AIDS Conference; Washington, DC, USA. July 22-27, 2012; abstr THPE562

54. Motshabi LC, Pengpid S, Peltzer K. HIV counselling and testing utilisation and attitudes of male inmates in a South African prison. SAHARA J. 2011; 8:107-14. [PubMed: 23237725]

55. Shalihu N, Pretorius L, van Dyk A, Vander Stoep A, Hagopian A. Namibian prisoners describe barriers to HIV antiretroviral therapy adherence. AIDS Care. 2014; 26:968-75. [PubMed: 24499371]

56. Noeske J, Mbondi Mfondih S, Kuaban C. Surveillance of HIV infection in new prison entries in Cameroon, 2008-10; 6th IAS Conference on HIV Pathogenesis and Treatment; Rome, Italy. July 17-20, 2011; abstr MOPE296

57. Manyonyi K, Rykunga C, Ediedu B, Gitia S, Mutuma N, Kimanzi S. HIV testing and counseling (HTC) using Rapid Results Initiative (RRI) targeting males in eastern province of Kenya; 19th International AIDS Conference; Washington, DC, USA. July 22-27, 2012; abstr THPE116

58. Makombe SD, Jahn A, Tweya $\mathrm{H}$, et al. A national survey of prisoners on antiretroviral therapy in Malawi: access to treatment and outcomes on therapy. J Infect Deve Ctries. 2007; 1:303-07.

59. Maggard KR, Hatwiinda S, Harris JB. Screening for tuberculosis and testing for human immunodeficiency virus in Zambian prisons. Bull World Health Organ. 2015; 93:93-101. [PubMed: 25883402]

60. Davies NE, Karstaedt AS. Antiretroviral outcomes in South African prisoners: a retrospective cohort analysis. PLoS One. 2012; 7:e33309. [PubMed: 22470448]

61. Hoffmann CJ, Fielding KL, Johnston V, et al. Changing predictors of mortality over time from cART start: implications for care. J Acquir Immune Defic Syndr. 2011; 58:269-76. [PubMed: 21876447]

62. Cornell M, Schomaker M, Garone DB, et al. Gender differences in survival among adult patients starting antiretroviral therapy in South Africa: a multicentre cohort study. PLoS Med. 2012; 9:e1001304. [PubMed: 22973181] 
63. Maman D, Zeh C, Mukui I, et al. Cascade of HIV care and population viral suppression in a highburden region of Kenya. AIDS. 2015; 29:1557-65. [PubMed: 26244395]

64. Diendere EA, Tieno H, Bognounou R, et al. Prevalence and risk factors associated with infection by human immunodeficiency virus, hepatitis B virus, syphilis and bacillary pulmonary tuberculosis in prisons in Burkina Faso. Med Trop (Mars). 2011; 71:464-67. (in French). [PubMed: 22235618]

65. Harries A, Nyirenda TE, Yadidi AE, Gondwe MK, Kwanjana JH, Salaniponi FM. Tuberculosis control in Malawian prisons: from research to policy and practice. Int J Tuberc Lung Dis. 2004; 8:614-17. [PubMed: 15137540]

66. Okorie O, Gidado M, Ekundayo E. Active case finding for pulmonary tuberculosis among prison inmates in Aba Federal Prison in Abia state; 45th World Conference on Lung Health of the International Union Again Tuberculosis and Lung Disease; Barcelona, Spain. Oct 28-Nov 1, 2014; $340-41$.

67. Zishiri V, Charalambous S, Shah MR, et al. Implementing a large-scale systematic tuberculosis screening program in correctional facilities in South Africa. Open Forum Infect Dis. 2015; 2:ofu121. [PubMed: 25884008]

68. Mangu C, Van Den Hombergh J, Kowour D. , et al. TB burden in Tanzanian prisons: active screening with Xpert MTB/RIF assay and esatablishment of associated characteristics for MTB infection; 45th World Conference on Lung Health of the Internation Union Against Tuberculosis and Lung Disease; Barcelona, Spain. Oct 28-Nov 1, 2014; 367

69. World Health Organization. Systematic screening for active tuberculosis: principles and recommendations. http://www.who.int/tb/publications/Final_TB_Screening_guidelines.pdf (accessed Jan 1, 2016)

70. Harris JB, Siyambango M, Levitan EB, et al. Derivation of a tuberculosis screening rule for subSaharan African prisons. Int J Tuberc Lung Dis. 2014; 18:774-80. [PubMed: 24902551]

71. Leung CC, Chan CK, Tam CM, et al. Chest radiograph screening for tuberculosis in a Hong Kong prison. Int J Tuberc Lung Dis. 2005; 9:627-32. [PubMed: 15971389]

72. Sanchez A, Gerhardt G, Natal S, et al. Prevalence of pulmonary tuberculosis and comparative evaluation of screening strategies in a Brazilian prison. Int J Tuberc Lung Dis. 2005; 9:633-39. [PubMed: 15971390]

73. Murray CJ, Styblo K, Rouillon A. Tuberculosis in developing countries: burden, intervention and cost. Bull Int Union Tuberc Lung Dis. 1990; 65:6-24. [PubMed: 2190653]

74. Getahun H, Kittikraisak W, Heilig CM, et al. Development of a standardized screening rule for tuberculosis in people living with HIV in resource-constrained settings: individual participant data meta-analysis of observational studies. PLoS Med. 2011; 8:e1000391. [PubMed: 21267059]

75. Mnisi TTJ, Govender I. Factors associated with pulmonary tuberculosis outcomes among inmates in Potchefstroom Prison in North West province. South Afr J Epidemiol Infect. 2013; 28:96-101.

76. Habeenzu C, Mitarai S, Lubasi D, et al. Tuberculosis and multidrug resistance in Zambian prisons, 2000-2001. Int J Tuberc Lung Dis. 2007; 11:1216-20. [PubMed: 17958984]

77. Lukoye D, Ssengooba W, Musisi K, et al. Variation and risk factors of drug resistant tuberculosis in sub-Saharan Africa: a systematic review and meta-analysis. BMC Public Health. 2015; 15:291. [PubMed: 25880829]

78. Rangaka MX, Cavalcante SC, Marais BJ, et al. Controlling the seedbeds of tuberculosis: diagnosis and treatment of tuberculosis infection. Lancet. 2015; 386:2344-53. [PubMed: 26515679]

79. Al-Darraji HA, Kamarulzaman A, Altice FL. Isoniazid preventive therapy in correctional facilities: a systematic review. Int J Tuberc Lung Dis. 2012; 16:871-79. [PubMed: 22410101]

80. South African Police Service. Strategy, research, monitoring and evaluation: annual report for the Commisioner of the South African Police Service 2014-2015. http://www.gov.za/sites/ www.gov.za/files/SAPS_Annual_Report_2014-15.pdf (accessed Jan 1, 2016)

81. Ruppel OC, Groenewaldt AL. Conditions of police cells in Namibia. http://www.kas.de/wf/doc/ kas_14189-1522-2-30.pdf?080715180451 (accessed Jan 1, 2016)

82. Stott KE, de Oliviera T, Lessells RJ. Combined antiretroviral and anti-tuberculosis drug resistance following incarceration. South Afr J HIV Med. 2013; 14doi: 10.7196/SAJHIVMED.957 
83. Springer SA, Spaulding AC, Meyer JP, Altice FL. Public health implications for adequate transitional care for HIV-infected prisoners: five essential components. Clin Infect Dis. 2011; 53:469-79. [PubMed: 21844030]

84. Baillargeon J, Giordano TP, Rich JD, et al. Accessing antiretroviral therapy following release from prison. JAMA. 2009; 301:848-57. [PubMed: 19244192]

85. Fontana L, Beckerman A. Recently released with HIV/AIDS: primary care treatment needs and experiences. J Health Care Poor Underserved. 2007; 18:699-714. [PubMed: 17675724]

86. Dos Santos MM, Trautmann F, Wolvaardt G, Palakatsela R. Rapid Assessment Response (RAR) study: drug use, health and systemic risks-Emthonjeni Correctional Centre, Pretoria, South Africa. Harm Reduct J. 2014; 11:11. [PubMed: 24708609]

87. Stephens T, Braithwaite RL, Reddy PS, Sifunda S, Bhengu S. Lifetime occurrence of sexually transmitted infection (STI) and substance use risk among prerelease South African prison inmates. Int Q Community Health Educ. 2006; 26:355-63. [PubMed: 17890181]

88. Adesanya A, Ohaeri JU, Ogunlesi AO, Adamson TA, Odejide OA. Psychoactive substance abuse among inmates of a Nigerian prison population. Drug Alcohol Depend. 1997; 47:39-44. [PubMed: 9279496]

89. Kinyanjui DW, Atwoli L. Substance use among inmates at the Eldoret Prison in western Kenya. BMC Psychiatry. 2013; 13:53. [PubMed: 23406288]

90. Parry CD, Pluddemann A, Louw A, Leggett T. The 3-metros study of drugs and crime in South Africa: findings and policy implications. Am J Drug Alcohol Abuse. 2004; 30:167-85. [PubMed: 15083560]

91. Naidoo S, Mkize DL. Prevalence of mental disorders in a prison population in Durban, South Africa. Afr J Psychiatry. 2012; 15:30-35.

92. Armiya'u AY, Audu MD, Obembe A, Adole O, Umar MU. A study of psychiatry morbidity and co-morbid physical illness among convicted and awaiting trial inmates in Jos prison. J Forensic Leg Med. 2013; 20:1048-51. [PubMed: 24237817]

93. Médecins Sans Frontières Operational Centre Brussels. MSF Malawi Prison Project Evidence for HIV Prevention in Southern Africa; Technical Forum-HIV prevention in prisons; Lusaka, Zambia. March 14-16, 2016;

94. Harm Reduction International. The global state of harm reduction. http://www.ihra.net/files/ 2015/02/16/GSHR2014.pdf (accessed Jan 1, 2016)

95. Mumba C, Malembeka G. Interventions to the improvement of access to HIV and TB testing and treatment for prisoners in Zambia; 7th IAS Conference on HIV Pathogenesis and Treatment; Kuala Lumpur, Malaysia. June 30-July 3, 2013; abstr MOPDC0104

96. ICAP. ICAP Expands HIV care and treatment in Swaziland's correctional facilities. http:// www.icap.columbia.edu/news-events/detail/icap-expands-hiv-care-and-treatment-in-swazilandscorrectional-facilities (accessed Jan 1, 2016)

97. Maggard K, Hatwiinda S, Phiri W. , et al. Inmate peer educators are essential to prison-based HIV testing and TB screening in Zambia; 19th International AIDS Conference; Washington, DC, USA. July 22-27, 2012; abstr THPDE0305

98. Ingabire E, Munezero D, Mugisha V., et al. Using detainees as peer educators in HIV prevention and systematic TB screening: Kigali Central Prison; 16th International Conference on AIDS and STIs in Africa; Addis Ababa, Ethiopia. Dec 4-8, 2011TUAC1203

99. Sifunda S, Reddy PS, Braithwaite R, et al. Effectiveness of a peer-led HIV/AIDS and STI health education intervention for prison inmates in South Africa. Health Educ Behav. 2008; 35:494-508. [PubMed: 18591222]

100. National Tuberculosis Programme, Ministry of Health. Malawi policy on tuberculosis control in prisons: fighting tuberculosis everywhere. Lilongwe: Government of Malawi; 2007.

101. Tuberculosis Control Programme, Ministry of Health. National strategic plan for prevention and control of tuberculosis 2015-2020. Lilongwe: Government of Malawi; 2014.

102. May JP, Andrews MC, Duverger KA. Priorities for healthcare in prisons of low income countries; Presentation to Thirteenth United Nations Congress on Crime Prevention and Criminal Justice 2015; Doha, Qatar. April 12-19, 2015; 
103. Ugandan Prison Services. EDF Human Rights (Prisons) Programme. http://www.prisons.go.ug/ index.php/reports-publications/41-projects/35-edf-human-rights-prisons-programme (accessed Jan 1, 2016)

104. Topp SM, Moonga CN, Luo N, et al. Exploring the drivers of health and healthcare access in Zambian prisons: a health systems approach. Health Policy Plan. 2016; published online May 24. doi: 10.1093/heapol/czw059

105. High Court of Botswana. Tapela \& others vs Attorney General \& others. http:// www.southernafricalitigationcentre.org/1/wp-content/uploads/2014/02/Tapela-Others-vAttorney-General-Others_22-08-14.pdf (accessed Jan 1, 2016) 


\section{Key messages}

- Despite global commitments to end HIV and tuberculosis, in the fourth decade of the HIV pandemic, most countries in sub-Saharan Africa do not collect or report comprehensive information about the incidence, prevalence, or clinical outcomes of HIV infection and tuberculosis in detainees, even though it is the region most affected by these diseases.

- Where data are available, the prevalences of HIV infection and tuberculosis in detainees in sub-Saharan Africa are almost always greater than those in nonincarcerated populations; detainees should be thought of as a priority population for HIV and tuberculosis interventions.

- $\quad$ Few countries have comprehensive prison HIV or tuberculosis policies or programmes, and, where programmes exist, they frequently cover only some detainees and provide inadequate services.

- Governments, donors, non-governmental organisations, and advocates urgently need to promote policy reform and guideline development to ensure the inclusion of incarcerated populations in national HIV/AIDS and tuberculosis programmes, with care provision and structured supervision consistent with community programmes. Specific requirements set by donors, regional governing bodies, and other multilateral organisations could contribute to advancement of both policy and service delivery to detainees.

- To ensure a data-driven and appropriate public health response, surveillance and quarterly monitoring systems, programme assessment, and operational research should be undertaken to ensure that the health needs of detainees are prioritised, ethically studied, and reported upon.

- Criminal-justice reform and conditions within prisons-including nutrition, substance use, mental health, infrastructure, and ventilation — should be prioritised by governments, donors, and human-rights advocates, and recognised as important areas of research, policy, and programme development. 


\section{Panel 1}

\section{Limitations of the data presented}

The aim of this Series paper is to provide an overview of the epidemiology of HIV and tuberculosis in prison populations in sub-Saharan Africa, the services available and challenges to service delivery, and priority areas for programmatically relevant prisons research. We did not do a systematic review of all available information; rather, we summarise publicly available grey and peer-reviewed literature published in the past 5 years (but also include older work when data were limited or not available). To supplement this information, we sought additional data from experts, which yielded very limited information, did case studies in specifically selected countries, and investigated funding for HIV and tuberculosis programmes within prisons. Detailed epidemiological descriptions of HIV and tuberculosis in prisons in each country of sub-Saharan Africa, and detailed, contemporary information about prison populations, HIV and tuberculosis policies, funding, and services are beyond the scope of this Series paper.

The quality of the epidemiological data included is variable, and should be interpreted with caution. All data identified are presented (appendix) without exclusion. As a systematic review was not done, some data published between 2011 and 2015 might have been missed. For each study included, details about the study period, number of prisons included, sampling methods, screening or diagnostic procedures, and case definitions are in the appendix. When interpreting the data, the generalisability of findings, sample sizes, potential biases, confounding factors that might be unaccounted for, and the comparability of findings with non-incarcerated populations, other studies, and over time should all be considered.

Between 2011 and 2015, there were 48 publications from 24 (of 49) sub-Saharan African countries-19 in peer-reviewed journals, 26 in conference proceedings, and three in institutional reports. Eight studies included no information about when they were done and 12 were done before 2011 (one in 2007, two in 2008, four in 2009, and five in 2010). In the 40 studies in which time to publication of data could be determined, 32 were published within 2 years, seven within 3-5 years, and one within 7 years.

Nine studies aimed to provide nationally representative prison data; the remainder were subnational, with 13 focusing on individual prisons. Therefore most data cannot be generalised to the country's total prison population. Different methods and case definitions were used in each study, which prevents easy comparison. In several, inadequate information was provided about the sampling methods, which means that selection bias cannot be fully explored. Some studies were done in a convenience sample or had poor uptake, which could result in selection bias. Routine notification or programme data were used in some, which could have led to underestimation of prevalence, whereas others were done in purposively screened populations.

In most tuberculosis studies, a positive symptom screen was needed before participants underwent microbiological testing, which could have led to underestimated prevalence; diagnostic tests with sensitivities less than $100 \%$ were used in many, and thus the number of cases could have been under-ascertained. Concurrent sampling of prison and non- 
incarcerated populations to allow a direct and valid comparison of the prevalence of HIV infection and tuberculosis between these populations was not done in any study. Trends in prevalence cannot be ascertained from the data. These limitations should be considered when using and interpreting the epidemiological data presented in this Series paper. 


\section{Panel 2}

\section{Experience of detainees in sub-Saharan African prisons}

\section{Pre-trial detention}

"I have stayed here for five years, and have not seen a plaintiff, and have not seen a judge. The court has not called the case."

Male detainee, South Sudan ${ }^{12}$

\section{Sexual violence}

"We called to the police and screamed for help, saying, 'These guys are forcing us to have sex with them.' But the police said, 'That is good, that's what you want.' So the police were encouraging the guys in there. There were about 50 other detainees, and five of them were raping us. Three of them raped me personally."

Male detainee, Tanzania ${ }^{13}$

Food

"Often there was no wood to cook, so [the deputised prisoner guards] would say, 'OK, spend the night without eating.' Once we went three days without eating. Even the children do not eat when there is no wood."

Male detainee, $R$ wanda $^{14}$

\section{Poor access to care}

"There are delays in getting to the clinic. It depends on the officials, if they want to take you there or not. Sometimes you can go as long as a month waiting to go to the clinic.... They don't open the door in the cell at night for anything. There are no windows, no air. Someone who was 28 years old died at night in my cell and they didn't open the door until the morning."

Male detainee, Zambia ${ }^{15}$

\section{Inadequate mental health care}

"When I was brought here, I didn't believe I would come out of that place [Juba Central Prison]. At night, people fight themselves. Some use razor blades. Others they insult, others they cry. Others are innocent. Others are angry. Others laugh but are not happy. Others are quiet. Others do not wear clothes-they move naked."

Male detainee, South Sudan ${ }^{12}$

\section{HIV care}

"I normally get my medicine once a month and I take it each day. I started ARVs in 2006, but when I was in Kwa Kabuga I did not get them."

Female detainee, Rwanda ${ }^{14}$ 
"When I told the prison officer I was HIV positive, he said, 'Fight on, complete the sentence, go home, and get treatment.' It meant he can't do anything for me. There were wardens I informed. They said prison has nothing to offer me."”

Female detainee, Uganda ${ }^{11}$

$\mathrm{ARVs}=$ antiretrovirals. 


\section{Panel 3}

\section{Experiences of children in adult prisons in Zambia}

Zambia has no dedicated juvenile justice system, and children in conflict with the law face trial in the adult court system. Even after an initial appearance before a judge or magistrate, juvenile detainees can wait for lengthy periods while their cases are being concluded.

One 17-year-old detainee told researchers, "I am here on remand; I came in July, 2007. I am done with my trial, just waiting for judgment... The trial didn't take too long, it is only the judgment that has taken long. It's been a year and four months since my trial ended. I've been back to court four times just for the judgment but it never comes."

International law mandates that people who are charged with a criminal offence be informed of their right to have access to a lawyer. However, many juvenile detainees in Zambia report no legal representation. Even children appearing before the High Court were rarely represented by counsel. As one teenage detainee reported, "I had no representation, I stood on my own behalf. It was my first time in a police station or in court. I was just speaking, and I was scared. So I didn't know what I was saying... As young people, it is very threatening to see the inside of the court. Even if you are not guilty, you end up pleading guilty."

Children held with adults often face sexual violence. "By the time we are discharged, we will go out of here with disease", said another adolescent detainee. "Juveniles are either taken advantage of or enticed because of our vulnerability. We are young, we don't have people to bring us food and clothes. They make sure we consume what they give, then are unable to refuse."

Access to health care, which is often difficult for adults, can be especially difficult for children. "Sometimes it is difficult getting to the clinic, sometimes you may not get to go. We ask the cell leader-[and even if they agree] the guards might say no", said a third detainee. Another 16-year-old concluded, "If you are sick, then you can't go to the clinic."

Source: Todrys \& Amon, 2011. 17 


\section{Panel 4}

\section{South Africa and Malawi-strong policies, but work still to do}

South Africa's prison system serves a prison population larger than any other African country and is administrated by a dedicated government ministry (table). Unusually in the African context, South Africa has both policy and stand-alone guidelines outlining a comprehensive package of HIV and tuberculosis prevention, diagnosis, care, and treatment actions (appendix). Malawi also has strong policies addressing prison tuberculosis services. The publication of the Malawi Policy on Tuberculosis Control in Prisons, ${ }^{100}$ which incorporates some actions on HIV, demonstrated unusual alignment of political and technical commitment, by recommending provision of entry screening, active case-finding, HIV testing, DOTS, antiretroviral therapy, and treatment follow-up for all post-release detainees with tuberculosis. The National Strategic Plan for Prevention and Control of TB 2015-2020 additionally articulated plans to align tuberculosis registration in Malawi's five largest prisons with Ministry of Health and National Tuberculosis Control Programme protocols, and to provide tuberculosis and HIV training for prison officers. ${ }^{101}$

Policies and guidelines provide an important framework for planning, financing, and implementation of HIV, tuberculosis, and other essential prison services, yet by themselves are insufficient. In South Africa, despite a well defined package of HIV and tuberculosis service entitlements and comparatively high levels of funding, key informants noted that prison health care remains suboptimal. All South African prisons have internal clinics but these clinics are understaffed. Lack of medical doctors (eight of 48 prison doctors' posts were filled in June, 2014) and a nursing act that prevents nurses prescribing without authorisation contribute to timelags and bottlenecks in chronicdisease management and increase dependence on non-governmental organisations to deliver tuberculosis and HIV testing and treatment. Prevention services are weak because nurses frequently are not adequately trained in primary care or preventive health. Infrastructural issues also limit tuberculosis infection control because prisons were not built to allow adequate airflow, and there is a high demand for isolation cells for purposes other than infection control (eg, for so-called trouble makers). High levels of stigma for HIV and a reluctance to report sexual abuse limit access to HIV preventive and treatment services. Continued treatment once detainees are released from prison has also proved problematic, and is exacerbated by inconsistent referral practices, reluctance of detainees to access services once released, and reported maltreatment of former prisoners in public health services.

Key informants noted that Malawi, too, is facing systemic barriers to realising its farreaching tuberculosis and HIV prison policies. Although the four largest prisons have static antiretroviral therapy clinics (registering around 600 detainees annually), the prison system struggles with human-resource capacity: only 20 health-care professionals are employed (one medical doctor, five clinical officers, five medical assistants, five nurses, and four microscopy technicians), with support from 30 patient-attendants. Challenges with supervision, supply chain, and disease notification are ongoing. In several smaller prisons, health services-including HIV and tuberculosis testing and treatment- are 
provided by visiting Ministry of Health staff, with occasional support from local or international non-governmental organisations. In many smaller sites, however, detainees must continue to be accompanied to external health centres. 


\section{Panel 5}

\section{Zambia and Benin—working outside the box}

Benin and Zambia have small absolute numbers of detainees by international standards but their prisons are severely overcrowded (table). Such conditions pose particular risks in relation to the spread of tuberculosis and HIV, and, in the absence of prison-specific policies, the evolution of HIV and tuberculosis care in prisons in these countries has been iterative (appendix).

Key informants report that health care in Benin's nine prisons is delivered by a small team of under-resourced nurses employed by the prison authority, La Direction de I'Administration Penitentiaire et de l'Assistant Social(DPAS). In recognition of the potential health threat posed by overcrowding in 2010, the country's national tuberculosis programme, Programme National contre la Tuberculose, Bénin (PNT, Bénin), recruited five new nurses, one at each of the five largest prisons. The nurses were tasked with providing HIV and tuberculosis counselling, conducting tuberculosis case-finding, collecting sputum samples, recording results, and overseeing referrals to PNT-run basic management units. Detainees with confirmed tuberculosis were also tested and treated for HIV. The nurses additionally provided general support to DPAS health staff.

In December, 2014, all five PNT-recruited nurses were absorbed (ie, employed and deployed by the Ministry of Health) in a national recruiting round, and, because of cost and supervisory complications, not replaced. In 2015, the PNT, Bénin announced a new policy to train DPAS nurses to do the same tasks. According to key informants, however, the capacity of existing staffto absorb the full suite of HIV and tuberculosis activities in prisons remains limited. So far, no specific policies for prison health, or prison HIV and tuberculosis services are being developed.

17 of Zambia's 87 prisons have internal health clinics. With only 34 health professionals employed (as of January, 2015), these clinics remain poorly staffed and resourced. At the central level, inadequate prison-health financing hampers implementation of healthworkforce planning and limits health surveillance and monitoring.

Despite these and other policy barriers, Zambia has made some gains in prison-based HIV and tuberculosis care and treatment. Funded by the TB Reach initiative of the Stop TB Partnership, the Zambia Correctional Service and the national tuberculosis programme in 2011 worked with non-governmental organisations to optimise HIV and tuberculosis detection among detainees, prison staff, and the communities in and around six of the prisons with the heaviest tuberculosis burdens. The same project also reinvigorated efforts to institute routine tuberculosis screening at entry and train a cadre of prison peer educators in several facilities. Under one partner-supported project, testing for tuberculosis with Xpert MTB/RIF (Cepheid, Sunnyvale, CA, USA) has been introduced in five Zambian prison clinics, along with protocols and training for staff. Concurrently, a second partner project supported the Zambia Correctional Service to form the first 11 prison health committees, comprising both officers and detainees, with a 
mandate to do facility-based needs assessments, basic service planning, and data collection. 


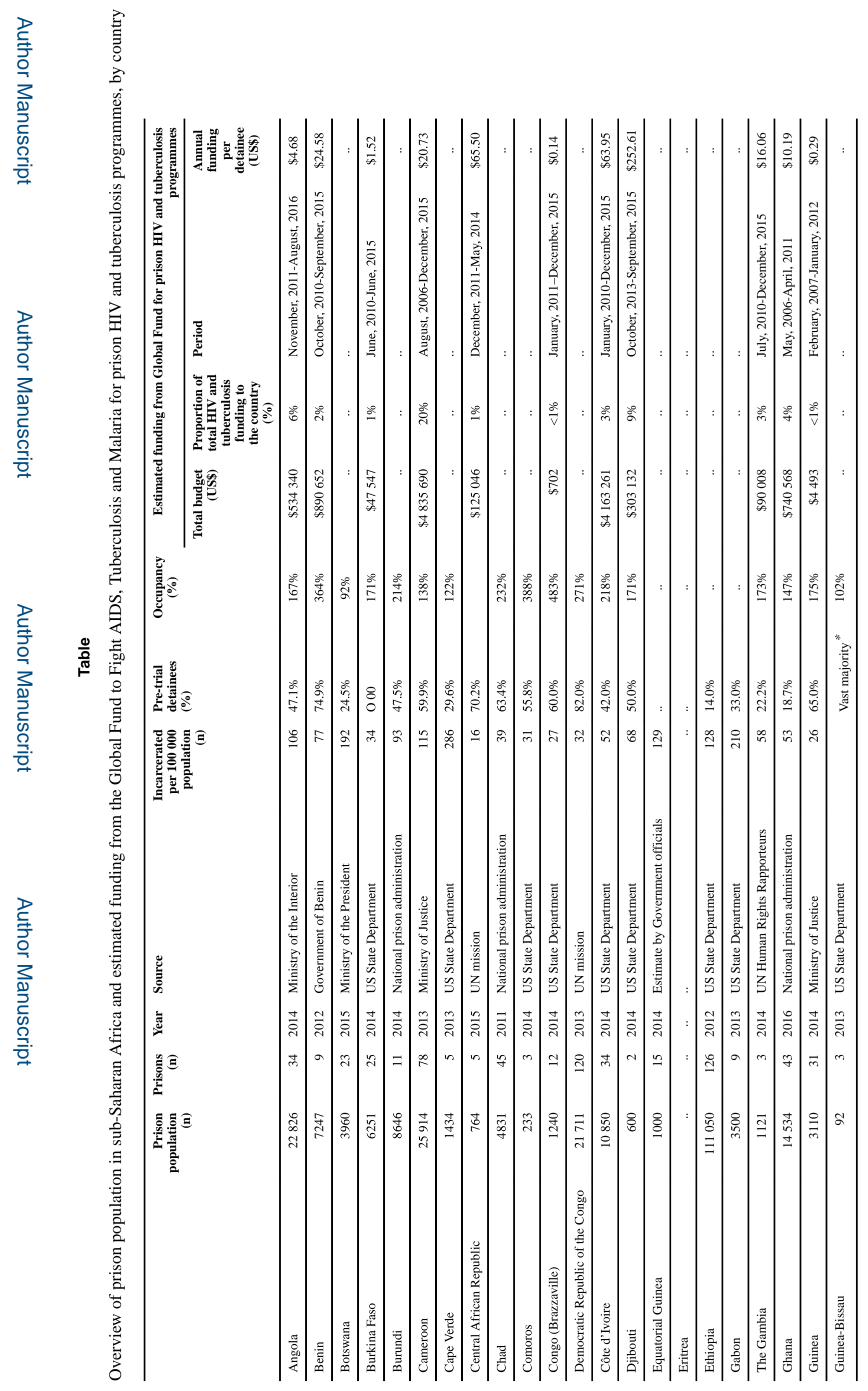


Telisinghe et al.

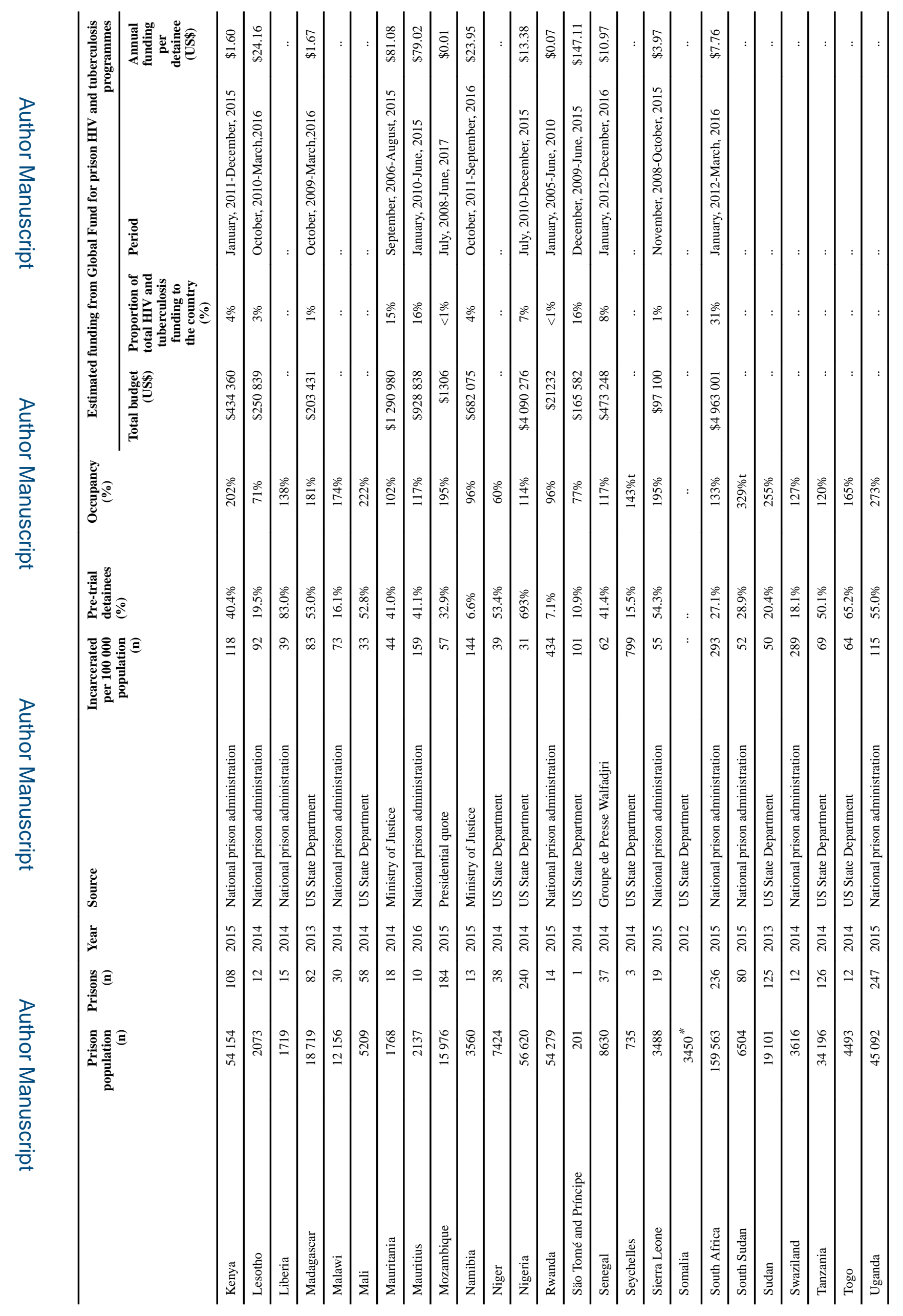




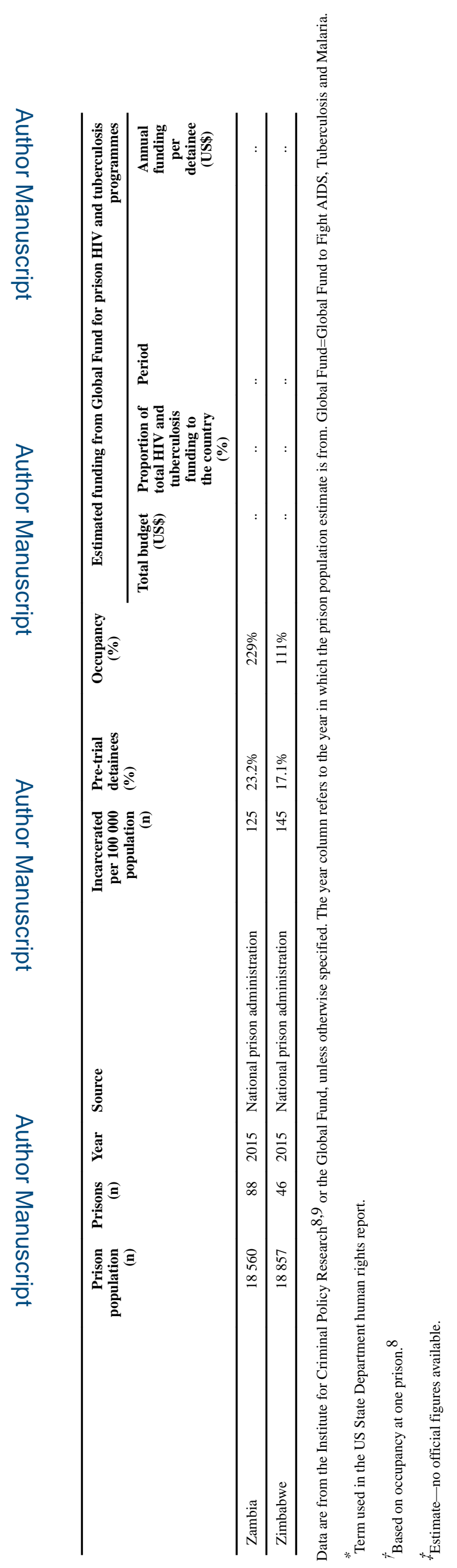

